OPEN ACCESS

Edited by:

Minna Kaljonen,

Finnish Environment Institute

(SYKE), Finland

Reviewed by:

Yiching Song

Chinese Academy of Sciences

(CAS), China

Theresa Tribaldos,

University of Bern, Switzerland

*Correspondence:

Juha Helenius

juha.helenius@helsinki.fi

Specialty section:

This article was submitted to Social Movements, Institutions and

Governance,

a section of the journal

Frontiers in Sustainable Food Systems

Received: 29 July 2020 Accepted: 20 October 2020 Published: 19 November 2020

Citation:

Helenius J, Hagolani-Albov SE and Koppelmäki K (2020) Co-creating Agroecological Symbioses (AES) for Sustainable Food System Networks. Front. Sustain. Food Syst. 4:588715. doi: 10.3389/fsufs.2020.588715

\section{Co-creating Agroecological Symbioses (AES) for Sustainable Food System Networks}

\author{
Juha Helenius ${ }^{1,2,3 *}$, Sophia E. Hagolani-Albov ${ }^{2,3}$ and Kari Koppelmäki ${ }^{1,2,4}$ \\ ${ }^{1}$ Ruralia Institute, University of Helsinki, Helsinki, Finland, ${ }^{2}$ Agroecology, Department of Agricultural Sciences, University of \\ Helsinki, Helsinki, Finland, ${ }^{3}$ Helsinki Institute of Sustainability Science (HELSUS), University of Helsinki, Helsinki, Finland, \\ ${ }^{4}$ Farming Systems Ecology, Department of Plant Sciences, Wageningen University, Wageningen, Netherlands
}

Critics of modern food systems argue for the need to shift from a consolidated and concentrated, often monoculture based agro-industrial model toward diversified, post-fossil, and nutrient recycling food systems. The abundance of acute and obvious environmental problems in the agricultural sub-systems of the broader food system(s) have resulted in a focus on technological and natural scientific research into "solving" these point of production problems. Yet, there are many facets of food systems that are vital to sustainability which are not addressed even if the environmental problems were solved. In this article, we argue for agroecological symbiosis (AES) as a generic arrangement for re-configuring the primary production of food in agriculture, the processing of food, and development of a food community to work toward system-level sustainability. The guiding principle of this concept was the desire to base farming and food processing on renewable bioenergy, to close nutrient cycles, to break away from the consolidated food chain, to be more transparent and connected with consumers, and to revitalize the rural spaces where farms generally operate. Through a consistent and robust collaboration and co-creative process with transdisciplinary actors, ranging from food producers, and processers to policy actors, we designed a food system model based on networks of AES (NAES). The NAES would form place-based food networks, replacing the consolidated commodity chains. The NAES supports sustainable interactions from a biophysical and socio-cultural perspective. In this paper, we explain the AES concept, give an overview of the process of co-creating the pilot AES, and a proposal for the extension of the AES, as NAES, to create sustainable food systems. Overall, we conclude that the AES model holds potential for creating place-based food systems that further the sustainability agenda.

Keywords: agroecology, circularity, post-fossil, sustainable transformation, co-creation, industrial symbiosis, bioenergy, plant nutrient recycling

\section{INTRODUCTION}

Critics of the current dominant food system argue for the need to shift from a centralized, agro-industrial model toward diversified, post-fossil, and circular food systems (Pimbert, 2009; Monteleone, 2015). This type of shift would mean a reversal of the trend of globalization and consolidation in food systems in favor of (re)localization (IPES-Food, 2016, 2017). There are 
well-justified arguments for abandoning the productionist agricultural model (Lang and Heasman, 2004), which include environmental, public health, socio-cultural, and economic reasoning (Marsden and Sonnino, 2012; Willett et al., 2019).

Along with the loss of important structural characteristics, such as local adaptations and diversity, the agro-industrialization of food systems has resulted in loss of the essential functional properties of stability and resilience. The excessive environmental impacts of these agro-industrial systems include the wasteful use of, and associated pollution and emissions from, the extracted natural resources, such as plant nutrients. In addition, the agroindustrial system contributes to loss of biodiversity, and loss of services from the ecosystems, such as pollination and carbon capture to soils. In addition, it contributes to the pollution and ecosystem impacts of plant protection chemicals. Globally, the current modes of food production are a major cause of exceeding the known planetary boundaries, particularly the ones of biological diversity, and nitrogen and phosphorus cycling (Steffen et al., 2015). The misconception of industrializing food and agriculture has resulted in extreme environmental degradation and destruction (Campbell et al., 2017; Willett et al., 2019). Failure to recycle the nutrients used in agriculture production is striking (Buckwell and Nadeu, 2016; Sherwood, 2020). The present system is highly dependent on external and excessive energy inputs, especially in the form of fossil fuels (Sherwood, 2020).

From a socio-culture perspective, the agro-industrial model (Figure 1) contributes to the homogenization of food supplies and diets (Khoury et al., 2014), and the fragmentation and homogenization of rural landscapes (Jongman, 2002). The fundamental set up of the industrial agricultural model renders the products of primary production placeless, as they move through middlepersons and into vast storage facilities. Food produced through the processes of the industrial agricultural chain has been likened to being from "nowhere" as the links between producer, processer, and consumer are complicated and difficult to trace (Schermer, 2015). There are also externalized costs of agro-industrial food systems, as they do not serve public health and create imbalance and inequity in entitlement to food. On one hand these agro-industrial food systems are contributing to diet-linked, non-transmittable diseases, and on the other hand they contribute to hunger and malnutrition (Tilman and Clark, 2014; Willett et al., 2019). One is justified to ask if agribusiness and the consolidated food industry on their own can make the transformations needed to transition to more sustainability oriented systems. Global and national food policies seem to be needed, and at the same time, transformative initiatives formed at the grassroots level need to be enabled.

These challenges appear to be as equally pressing as the need to reverse the food systems disproportionate contribution to and impact from global climate change (Wheeler and von Braun, 2013; IPCC, 2019). The globally shared commitment to every persons' entitlement to food and adequate nutrition is derived from Article 25 of the Universal Declaration of Human Rights (UN, 1948), which provides a clear goal for improving food systems. The stark failure of the conventional food chain in addressing human rights is well-documented, but largely ignored

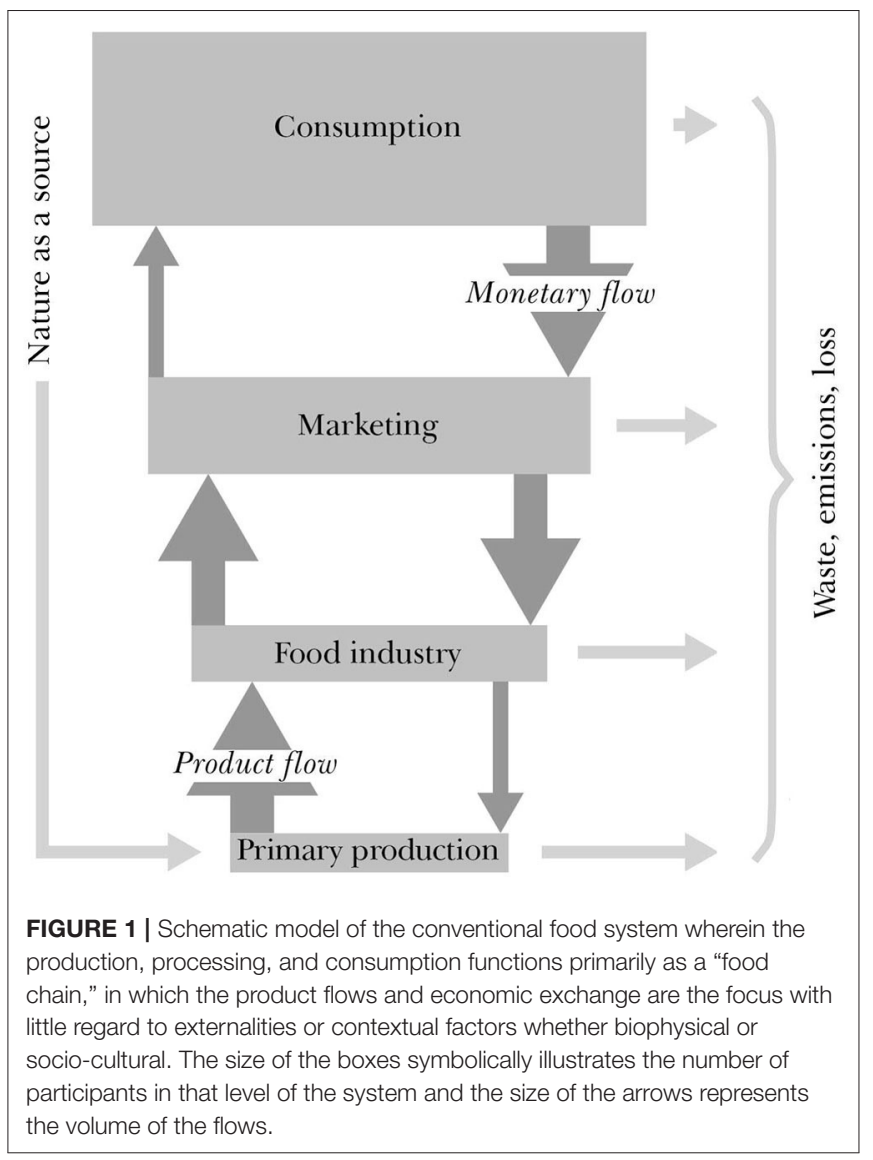

even in (food)policies, not to mention the commodity-based agribusiness (De Shutter, 2010). The dominance of consolidated food chains threatens food security and leaves the food system vulnerable, with little resilience to external disturbance. In the context of the Covid-19 pandemic, this concern was publicly brought up by news media, as the centralized meat chains in several countries stumbled (see for e.g., van der et al., 2020).

The socio-cultural impacts of the globalized food system revolve around the homogenization of food cultures, the physical and cultural distancing of an increasing majority of "consumers" from the producers, and associated loss of sense of food. By the concept of sense of food, we mean a loss of understanding about the food one consumes in its full place-based context (Wilkins, 2005; Kneafsey et al., 2008; Spiller, 2012). These developments have had the alarming consequence of resulting in lack of public interest in food policy, or in insufficient policies. Calls for increased food sovereignty-food systems that are designed to accommodate the context and needs of the participants in the system (Rosset, 2008; Patel, 2009; Clapp, 2016)-and agroecology as a movement (Wezel et al., 2009) have emerged as a response, but often represent resistance and alternatives rather than full systemic transformation. From an economic perspective, the industrial food system and the "cheap food" it produces, creates imbalance and dysfunction (Patel and Moore, 2017). It has contributed to the decline of rural livelihoods, 
farmer incomes, and to a vicious cycle of an ever-increasing need for intensification to maintain yields from agricultural land (Tilman et al., 2002; IPES-Food, 2016).

In the context of addressing the need for transformative change of the food system, many if not most of the scientifically well-founded analyses focus only on parts of the food system, which appears as only a partial optimization, or even redundant. This is especially true in attempts to improve sustainability of agriculture by tinkering around with the details of the agricultural system while taking the rest of the system for granted. In other words, agriculture cannot achieve sustainability separately from the wider food system, where it is a foundational building block. This understanding is emerging, even if it is still only partially addressed, in the ongoing debate about "sustainable intensification" of agriculture (Rockström et al., 2017). The abundance of acute and obvious environmental problems in the agricultural sub-systems of the broader food system(s) have resulted in a focus on technological and natural scientific research directed at "solving" these point of production problems. Within agricultural sciences, agroecology with its sustainability science orientation and multiple facets - that is as a science, practice, and socio-cultural movement-serves to address sustainability at the food system level (Francis et al., 2003; Helenius et al., 2019).

Developing food system(s) to support sustainability is a typical "wicked problem." The problems of the food system cannot be directly "solved" by science alone (Rittel and Webber, 1973). The systematic integration of other types of knowledge is needed to begin to approach the sustainable transformation of food systems. There is also need for citizen led initiatives and scientific processes supported and augmented by food system participants at multiple levels. Involving persons living and working within the agricultural system carry knowledge about the system that cannot always be gleaned from top-down science and policy (Schillo and Robinson, 2017). Yet, the introduction of new actors and modes of collaboration has potential for creating tension and must be administered thoughtfully and in a way which respects the context of the transformation (Keune et al., 2015). Even with the introduction of co-creative processes and engagement of transdisciplinary actors and citizen scientists there are no simple solutions when it comes to food system redesign. Each facet of the food system has many sub-facets that must be taken into consideration when seeking transformational change. For example, this becomes obvious when looking at how the challenge of transforming almost any aspect of the food system links (FAO, 2018a) to the 17 sustainable development goals of the United Nations (SDGs: UN, 2015). Yet, there are some emergent and promising food systems models which speak to food system redesign and supporting a sustainable, holistic food system. Transformative change requires supportive policy mixes and governance (Geels and Schot, 2007; Diercks et al., 2019), which are outside of scope of this article. However, we witnessed this through a co-creative process with the involved non-science actors, for example the farmers, entrepreneurs, and consumers in place. All these parties came together and participated in the development of a food system model that, as we argue, deserves full attention for supportive and enabling policies and governance. In this article, we argue for agroecological symbiosis
(AES: see Figure 2) (Koppelmäki et al., 2016, 2019; Helenius et al., 2017) as a generic model for re-arranging the primary production of food, from the agricultural and processing perspective, toward sustainability. Furthermore, we propose that using AES as the organizing principle to form networks of agroecological symbioses (NAES: Figure 3) would serve sustainable transformation at food system level. In this paper, we will: (1) explain the concept of AES; (2) propose a network of AES (NAES) as a foundation for a sustainable food system; (3) discuss the sustainability of NAESconcept based on analysis on Huber's (2000) generic framework of transformational strategies toward sustainability in context of industrial ecology; and ultimately, (4) we will describe the co-creation process from the first AES pilot case to the further implementation of the concept.

\section{AGROECOLOGICAL SYMBIOSIS (AES)}

By our definition, an AES is a food production and processing industrial symbiosis that runs on renewable energy derived from its own feedstocks (Figure 2).

\begin{abstract}
Definition for Agroecological Symbiosis (AES) Agroecological symbiosis-AES-is a form of food production and processing in which the farms, the food processors, and the energy producers function in an integrated manner. The operations are running in spatial proximity to each other allowing efficient material and energy integration. In an AES, nitrogen as plant nutrient for the primary production is biologically fixed. The main source of energy is renewable, generated from the biomasses produced within the AES in a biorefinery, such as a biogas plant, belonging to the AES. In case of a biogas plant, the biorefinery has the dual purpose of providing the energy, and in the form of the digestate, producing the organic fertilizer and soil-conditioner for recycling plant nutrients back to the farmland. An AES sells agricultural or horticultural products, food products, and if produced in excess, bioenergy. The volume of the production, and the reach to the surrounding farmland within the AES are limited by the biophysical potential of the specific agroecosystems without compromising the other ecosystem services. The spatial extent of the biophysical operations is limited to sustainable logistic efficiency for the transport of the feedstock and the recycling fertilizers. The AES strengthens the local socio-economic connections and diversifies the regional food culture.
\end{abstract}

The term agroecological symbiosis (Koppelmäki et al., 2016) stems from the concept of industrial symbiosis, which-with extensions-we applied to the food chain. Chertow (2000) describes how mutually beneficial inter-firm cooperation, as an application of industrial ecology (Frosch and Gallopoulos, 1989; Graedel and Allenby, 2010), can be organized to form "industrial symbiosis," such as eco-industrial parks. Chertow (2000) argues for the benefits of the spatial proximity of the industrial partners who seek to maximize resource efficiency from minimizing the waste of materials and energy through forming a symbiosis. In the pilot AES, described in section Co-creation in the Palopuro pilot project below, the biophysical range was within a radius of approximately $15 \mathrm{~km}$, but this may vary widely from one agroecological region to another. As we describe in the following 


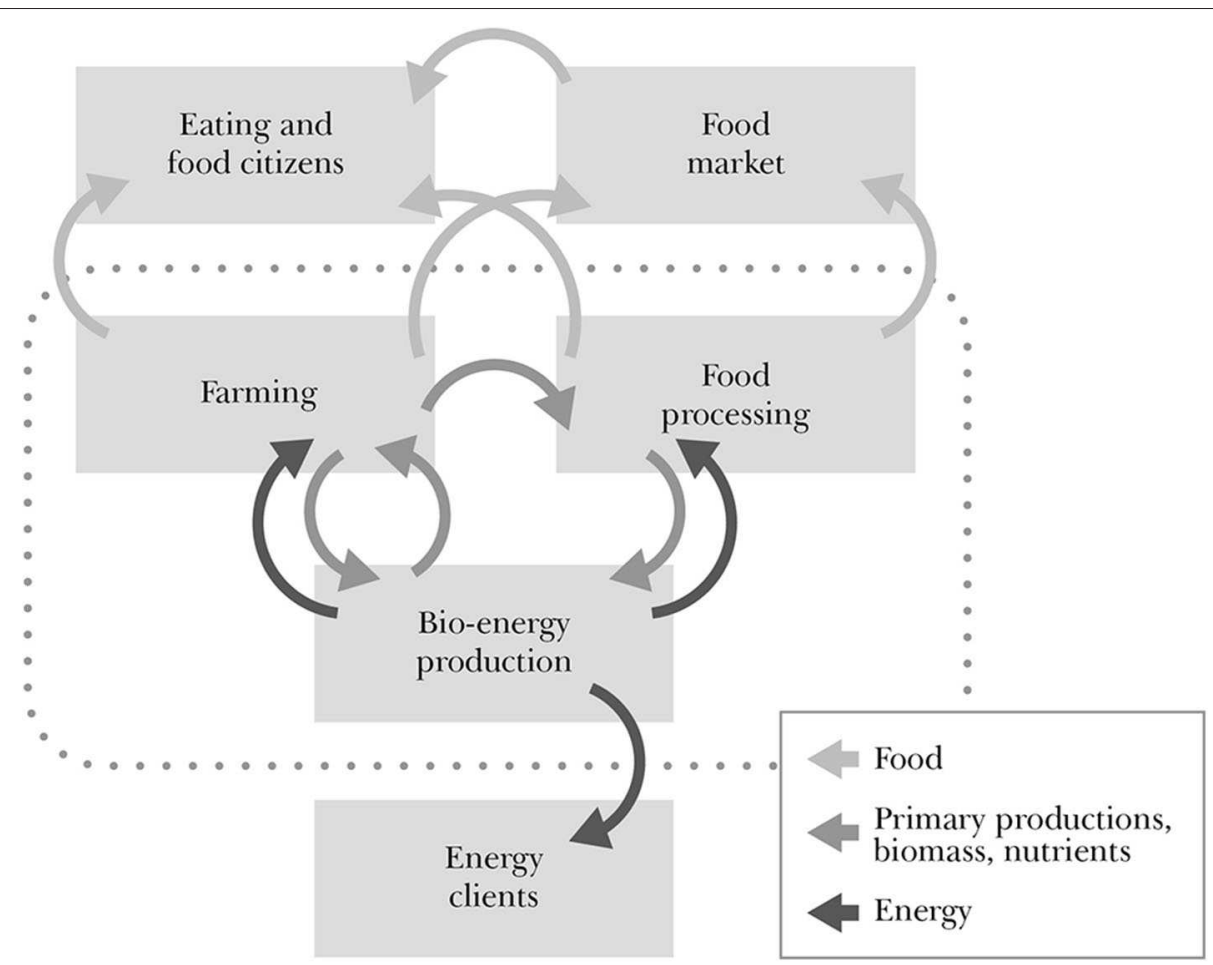

FIGURE 2 | Schematic model of an agroecological symbiosis (the AES itself is represented within the dotted box). It is a recycling, bio-energy self-sufficient industrial symbiosis of farm(s), an energy producer, and food processor(s). It produces contextual food identifiable to consumers, either directly or via the market, with an emphasis on localized production, processing, and consumption. The AES brings the people who eat to the community it creates, bolstering the creation of a food community. The arrows within the AES represent primary product flows, recycling of plant nutrients, and bioenergy. The arrows from the AES represent flows of products: food and any excess bioenergy to the market.

sections, agroecology as a prefix refers not only to ecological outcomes of the redesigned food system model, but also to socio-economic and to cultural outcomes.

\section{Organizing Principles and Functions}

Food production inseparably relies on ecological primary production through photosynthesis of plants, and (not obligatorily) on secondary production of livestock fed with plants. Diverse food products are produced through the industrial processing of agricultural plant or animal "rawmaterials," but the energy, the proteins, and the nutrients (some mineral or synthetic vitamin additives as exceptions) of food originate from farmed crop plants grown in farmland soil. From the ecosystem origin of food, it follows that all that is required for ecological sustainability of the use of ecosystems in general, applies to food production and agricultural ecosystems specifically.

An essential condition to ecosystem functioning is ecological integrity, which depends on biological diversity within the ecosystem (Hooper et al., 2005). This integrity is, in principle, similar to what is required for the functioning of mechanical machines as systems with many subsystems and parts, for example engines or computers. The difference is that ecosystems - and life-are orders of magnitude more complex than anything humans have ever manufactured. The lack of understanding of the structural details, the role of species diversity, the feedbacks, and the fine-tuning that exist in lifesupporting systems, i.e., the ecosystems, must at least partly explain their neglect in decision making. The social psychology of continuous ecological destruction (Oskamp, 1995) is outside of scope of this article, but it must be closely linked to growing loss in increasingly urbanized societies of the sense of food and the understanding of the ecosystem as the origin of food.

Awareness of place and the embeddedness of agriculture goes hand in hand with the concept of sense of food, and is a necessary component in developing a (re)localized production and consumption system (Murdoch et al., 2000; Feagan, 2007). Place is a concept that is essential to both the producer and consumer sides of food systems, as it transcends both the physical and the socio-cultural valuation of any specific food product (Feagan, 2007; Cresswell, 2013). Every single agricultural product that is grown in the world has a physical location, a discrete space where it came into being. In addition, every food item that is consumed in the world is also rooted in the physical action of biological primary production (that is growth), which takes place in a real physical space. Even as the ease of transportation has created a smaller seeming world; technology still has not created a provision to provide "wireless" calories, or "landless food." The social disconnection from food production continues to happen at multiple levels, including biophysical and social (Dorninger et al., 2017). This disconnection has been articulated as the metabolic rift (Foster, 1999; Wittman, 2009; 


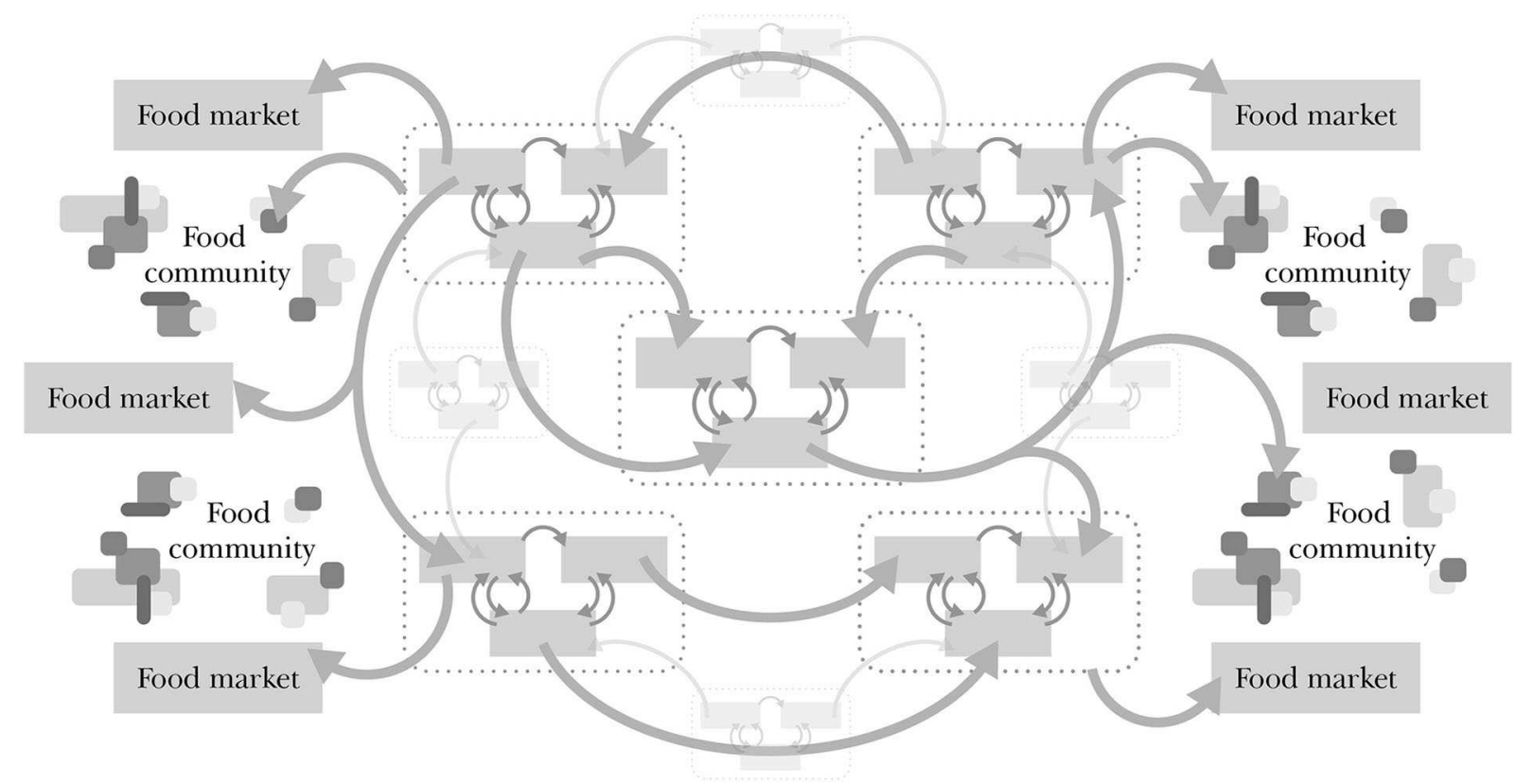

FIGURE 3 | Schematic model of the agroecological symbioses (see this figure for a detail of an individual AES) forming a localized food production and processing system, an AES network (NAES). The NAES is an open system. The AESs can serve in neighboring NAESs, and together, the NAESs form a regional grid that connects to a national, and even a global meta-system. It represents a circular economy, runs largely on its own bioenergy with high climate-efficiency, and forms a foundation for a cyclical, adaptive, and resilient food system. In this system, the consumers become sovereign members of a food community created through the shared NAES. They gain an increased sense of food, and sense of place in the agroecological context of the NAES.

Schneider and McMichael, 2010), which extends across both the biophysical and social metabolisms of food production, process, and consumption.

The number one consideration for an AES is that while the agroecosystems are managed to serve the production needs, at the same time the needs of the system also must be served. In anthropocentric terms, serving ecosystems aims at maintenance of their ecological integrity, as an essential condition for continuous productivity. In AES thinking, ecosystem services are reciprocal rather than a one-directional concept (Comberti et al., 2015). The ecosystem has multiple functions in the mosaic that comprises the biosphere; while it is still used by humans to extract products and value, humans are obliged to return these services.

The number two consideration is recognition of agroecosystems as subsystems in the wider food systems. City dwellers living solely in metropolitan areas may well-hold escapist illusions of being decoupled from agroecosystems, yet with every mouthful of food they most concretely, physically link upstream to the material and energy flow of the food from the farmland field ecosystems that comprise their foodsheds (in an analogy to watershed, Kloppenburg et al., 1996). Spiritually, if this aspect can be acknowledged, eating is an everyday sacrament, devoted to the food's ecosystems of origin. This sacrament includes acknowledging the work fellow-citizens do in the food chain, but essentially, it represents a personal and essential biophysical linkage to the ecosystems, and to the life-supporting integrity of the biosphere at large.
Food systems need to be adaptive and resilient. It follows from their place-bound ecosystem foundation that adaptiveness and resilience must emerge at each place of production, down to the most local farm scale. From the local scale, these properties can then be expanded to wider system scales.

From the above considerations we propose an AES maintains and as needed, increases and improves:

1. biological diversity, the ecological community essential for ecosystem function;

2. abiotic soil, water and atmospheric condition required by the ecological community;

3. recycling of elements, called plant nutrients that the process of primary production of crop plants take up, but need again for the next harvest;

4. energy-self-sufficiency of the system through its primary production by photosynthesis of solar energy;

5. psychological, socio-cultural (mental, spiritual) connection to the food ecosystem of the people who eat through fostering a sense of food and food citizenship.

\section{NETWORKS OF AES (NAES) AS A FOUNDATION FOR A SUSTAINABLE FOOD SYSTEM}

As complementary modules in an interacting network of AESs, the AESs form a foundation for a transformative food system. Conceptually, a network of agroecological symbioses (NAES), 
represents a distributed model for the food processing industry. It redefines the vertical integration between the processor and the primary producer: the farmers in the AES sell primary products directly to their processing AES partners, which increases the transparency in the production system as one can track the journey of particular primary products into production. The communication is direct. In the conventional system, the farmer usually sells the commodity to an anonymous commodity market, often to middlepersons running centralized storage facilities. Farm products are not often sold directly to a specific processor and often are mixed into a bulk of "commodity," which results in losing knowledge about the origin of specific primary products during the journey through consolidated industrial processing. NAES also adds horizontal integration that is lacking in the conventional system. This integration is between the AES-units of production and processing. This can be visualized as working within the context of the rural landscape as the specific configure of the integrated entities is malleable within each AES. The key is spatial proximity and a scale consistent with requirements of the ecosystems' economy-not just the bioeconomy-and circular economy. In practice, spatial proximity is determined by the extent to which it is economical to transport biomasses such as manures, (other) recycling fertilizers, or feedstock for bioenergy. Within a NAES, each AES contributes, with its own food and energy production, to the total production of the NAES. The individual AESs specialize in seeking optimal roles within the reality of their individual production capacities. These capacities converge at the NAES level.

By definition, a NAES is a network of many AESs. A NAES forms a foundation for a local food system, when it produces food products from its agroecological context to the market and to the people who eat those products (Figure 3). When forming a national and global grid, at the meta-NAES level, the NAESs are building blocks for a sustainable food system.

Wezel et al. (2016) proposed "agroecology territories" as territorial sustainable food systems. We find the NAES would be a food system model for such a transformation. Wezel et al. (2016) criticize the narrow emphasis on sustainability of a single agricultural commodity production, or on a single food product chain. With its emphasis on adaptation of agricultural practices to local and regional agroecological conditions, and on embedded food systems, the agroecology territories concept is consistent with the NAES concept. Wezel et al. (2016) list within-territory conservation of biodiversity and natural resources as conditions for the biophysical adaptation. NAES adds reliance on renewable energy produced within-territory, and recycling of plant nutrients. Owen et al. (2020, p. 2) propose that "geographical indications" (GIs) as a rural development mechanism that can serve in delivering transitions to agroecology territories, to "quality-led, place-based food systems." In the GI scheme, a value-adding geographical indication can be administratively granted to a product (EU, 2020). Owen et al. (2020) cite Bowen's (2011, p. 326) definition of a territory as "a space that is socially constructed, culturally marked, and institutionally regulated." They call upon stakeholders adopting a territorial governance approach consistent with the Food and Agricultural Organization's "10 elements of agroecology" (FAO, 2018b). GIs are consistent with, and would serve in supporting, the transition to NAES.

As an organizing principle for the food system, NAES contrasts with current industrial consolidation and the type of vertical integration, the monocultural concentration, characteristic to globalizing food chains. These treat food as a manufactured product, and the farmed products as commodities without recognition of food systems' unique biosphere-base in agricultural ecosystems, and their socio-cultural foundation in the rural landscape.

Industrialization of the food system goes hand in hand with discourses of "feeding the world." The principle of adapting the food system to a safe operating space set by the (agro)ecosystem directly challenges the idea of feeding the world at any cost. This position is echoed in other strands of the discourse, for example, in the polarized debate concerning whether food security is only possible through further intensified industrial agri-business, or only through the widespread uptake of organic farming (Connor, 2013; Eyhorn et al., 2019). It is obvious that planetary boundaries exist, which sets a ceiling to how big a population can "be fed” (Rockström et al., 2017). Food policies need to be explicit about their positioning regarding the underlying balance between population size and quality of life, including the quality of food and nutrition. Population increase enforces drivers that may push toward tipping-points of the system, result in loss resilience, and generate reactive rather than proactive regime shifts (Pereira et al., 2020). In advocating the principles of circularity, reciprocity of ecosystem services, reliance on selfproduced non-fossil energy, and engagement of the people who form the food community, NAES suggest discourse of ensuring entitlement to food and nutrition, more a "right to eat," rather than "right to become fed."

With any combination of farming practices, diets, food cultures, and population size, there is a ceiling set by the carrying capacity of the biosphere. How the key questions are answered of who produces what, where, how, and to whom, there still looms a planetary boundary for increasing the production. This speaks to the far to future reaching vision of NAES for dynamic, but harmonic equilibrium between population and use of the biosphere for food production. It reinforces the idea of food sovereignty-but not individuality - as the NAES food communities define their own food, but are also entitled to their food production systems.

In contrast to the conventional, increasingly delocalized or globalized, and centralized food production chain of the industrialized countries (IPES-Food, 2016, 2018; Ellen MacArthur Foundation, 2019), NAES as a generic model would result in a "glocalized" (e.g., Quaye et al., 2010) and distributed system of food production. In terms of food cultures, it would result in diversification as opposed to the current trend of homogenization (Ritzer, 2013; Clapp, 2016). Such a reorganization would boost rural livelihoods, and would have implications to structural developments in the society, including the current unsustainable and fossil-fueled trend of urbanization toward metropoles. Without trying to explore the issue of urbanization further, we express our deep concern about the possibility to "feed the big cities" within any sustainable realm 
at the same time when people are abandoning the regions where food is produced. Without prior planning nor control, the cities simply mushroomed as products of the fossil fuel era. The metropoles are comparable to feedlots in animal farming, highly unsustainable, highly dependent on continuous feeding from the global rural. Food communities around NAES are best when local; the NAES-based food system offers a possibility to sustainably de-structure the big cities. To achieve this goal in addition to other supports for sustainable food systems, policies for "ruralization" need to link with food policies.

NAES gives the promise for increased food sovereignty and resilience in terms of food security. It gives promise for transformative change from extractive food capitalism toward sustainable ecology-based food systems. This is a functional model of human-scale agriculture that is flexible to be adapted for the local contexts it inhabits (Condon et al., 2010).

\section{EFFICIENCY, SUFFICIENCY, AND CONSISTENCY OF NAES}

In the following sections, we use Huber's (2000) framing of efficiency, sufficiency, and consistency to explore the promises for sustainable transformation in the NAES food system model. We took the liberty to interpret what Huber presented as complementary strategies, as criteria for sustainable transformation. All three criteria need to be met to achieve a sustainable transformation in a production and consumption system. By consistency, Huber (2000) refers to coherence with the wider goals of environmental sustainability. We found this framing useful because it speaks to the viewpoints and driving motivations of multiple actor groups within sustainable transformations.

In discussing industrial symbiosis, Chertow and Ehrenfeld (2012) point out the need for explicit recognition and institutional support as enabling factors, if such symbiosis is adopted as an organizing principle for sustainability transformation. There is the pitfall of eco-efficiency being a winning strategy for the business through financial savings, while ignoring the rebound effect and hence, not resulting in ecological savings (Hukkinen, 2001; Heikkurinen et al., 2019). In any case, technologies and policies enabling eco-efficiency are surely welcomed by industry. At the same time, there is a public interest in policies that control the rebound effects, ensure sufficiency as a ceiling to material growth, and govern for consistency-in both meeting societal goals and the grand planetary challenges.

\section{Efficiency of NAES}

In generic terms, ecological efficiency simultaneously allows further economic growth and ecological adaptation of industrial production (Huber, 2000). In the context of food production systems, increasing efficiency means producing more food per unit of resource used. In crop production, efficiency is commonly measured by a ratio of quantity of product (harvest) to area of agricultural land harvested. Emphasis on land productivity tends to leave other natural resource efficiencies unnoticed, even though water, nutrients, and energy efficiencies are equally important. For example, nutrient use efficiency (NUE) measures how well-crop plants use the available nutrients for the harvestable product (Reich et al., 2014). Similarly, in livestock production, the feed conversion ratio measures the ratio of feed inputs to food outputs (Garnett et al., 2015). Nevertheless, these all are efficiencies measured at process level, or at subsystem level within a system, rather than indicators of system level efficiencies.

For understanding system-level efficiencies, it is essential to understand through what kinds of feedback the processes within sub-systems operate, and how the sub-systems are connected to other parts of the food system at different spatial and temporal scales. Field scale efficiency is not equal to farm scale efficiency. Similarly, farm scale efficiency does not guarantee efficient use of resources at regional or wider geographical scales. This disconnect is demonstrated by the following example. A crop farm using mineral fertilizers may produce high yields of cereals utilizing a relatively small fertilization. In other words, the ratio of outputs to inputs is high. A livestock farm, located next to the crop farm, produces moderate yields by applying high quantities of manure as a fertilizer, which results in a much lower ratio of outputs to inputs when compared to the crop farm. A simple conclusion is that the crop farm has a better NUE. However, when considering efficiency, it is essential to take also into account what happens after harvest. If the cereals harvested on the crop farm are used as feed on the livestock farm, the NUE looks different when considering both farms as a single continuous feed/animal production system. Furthermore, the origin of inputs and the quality of output varies on these farms. This implies that conclusions about efficiency cannot be derived by observing efficiencies at the sub-systems' level only, or only at a small spatial scale when the feedbacks reach larger scales.

In the current conventional agricultural sub-system of the food chain, two trajectories have had a substantial impact on efficiency. First, a low-cost feed transport has enabled livestock farms to concentrate and to spatially disconnect the animal husbandry from local feed production and secondly, mineral fertilizers have enabled farms to increase crop per-unit-area productivity while simultaneously releasing farms from the need-or possibility-to recycle the plant nutrients in crop production. As a result of this specialization at the farm and regional levels, nutrients are concentrating spatially; nutrients are dislocated and recycling is disrupted (Buckwell and Nadeu, 2016; Schulte et al., 2019; Parviainen and Helenius, 2020; Koppelmäki et al., 2021). What has looked like increasing efficiency in crop and in animal production has in fact been a dramatic decline in efficiency of the use of plant nutrients at the food system level, and an inefficiency in producing food.

Instead of increasing efficiency at the sub-system level, while sacrificing it at the whole-system level, the aim should be in system's efficiency. This is what NAES provides, it allows for explicit system level efficiency indicators and improvement (Koppelmäki et al., 2021, submitted manuscript). The requirement of circularity alone is a strong incentive for example, to the farms of the NAES to match the number of animals with the local feed production, in case NAES produces foods of animal origin. Feed imports from outside the 
agroecological region where the AES functions do not match with the concept, and if done, need costly arrangements for recycling the plant nutrients back to the feed producing farms. By-products from the food system, such as plant nutrients recovered from food waste and from municipal sewage, represent recycled resources within an NAES-based food system.

The requirement of reliance on internally sourced bioenergy, linked with the system's property of biological nitrogen fixation makes NAES by far more climate efficient than systems that rely on fossil fuels and on industrial nitrogen fixation, such as present industrial farming. In addition, requirements for increased rotational diversity, increased share of leys in the rotation, and use of organic recycling fertilizer, such as the digestate, serve stocking carbon to soil and reversing the current loss of carbon from farmland.

In the context of sustainability, efficiency as a system's output per unit of negative environmental impact generated also needs to be quantified, or at least qualitatively assessed. For example, at what rate per unit product does the food system cause biodiversity loss? Expressed this way, the expectation of increased biodiversity would return a negative value for a positive trend.

We argue that redesigning the system of primary production and processing of food along the lines of the NAES concept increases efficiency at food system level. As a food web rather than a food chain, NAES can produce more food energy and protein per unit farmland area, with less nutrient loading and less atmospheric emissions per unit farmland, and per unit of food produced, than would be the case if the production continued conventionally. Compared to current conventional practice, agroecological benefits include increased organic matter input to farmland soil, diversification of crop rotations, maintenance of soil organic matter and soil fertility, increased or even full self-sufficiency on biologically produced nitrogen, practically full recycling of phosphorus and other mineral plant nutrients (Koppelmäki et al., 2021, submitted manuscript), and radically improved climate-efficiency per hectare of farmland and per unit product. NAES makes it possible not only to enhance ecosystem services to production, but also to serve the ecosystems in maintaining their biological diversity, integrity, and function.

\section{Sufficiency of NAES}

Huber (2000) argues that efficiency can only be an intermediate for sufficiency. The concept of sufficiency encompasses a strategy involving consumption patterns and lifestyle, explicitly asking the question, how much is enough? (Huber, 2000). The need to ask this question follows from the limited planetary operation space. In food systems, the most critical factors to what becomes "too much" are population and diet.

Increasing efficiency in agricultural land use seems to give temporary relief, while simultaneously, global analysis already emphasizes the need for controlling diets (Foley et al., 2011), and even population (Crist et al., 2017). During the last decades, the area of agricultural land necessary to feed one person has deceased, but population growth and dietary change have offset the potential land savings from this increased productivity (Kastner et al., 2012). In NAES, the volume of primary production is limited by the agroecosystem's biophysical potential to produce biomass without substantially relying on external nutrient and biomass inputs.

In the "feeding the world" discourse there is a lively and persistent side-stream, the land sparing vs. land sharing debate (Loos and von Wehrden, 2018). The proponents of land sparing argue for increasing productivity of the existing farmland as a means to save nature (which in this thinking, is found outside of farmland). The productivity would be increased by increasing input intensity. As a rule, this camp ignores the fact that the path of intensification has come to an end (Tilman et al., 2002), hitting the wall of ecological sustainability. The proponents of land sharing argue for farming that would allow wildlife to share the farming environments with crops and cattle. This sharing would aim to wider biodiversity goals than simply maintenance of the "ecosystem services" of farming (Zhang et al., 2018).

Obviously, "sustainable intensification" (Rockström et al., 2017) would be sustainable, and wherever ecological space there is for it, it may push the population-times-diet limit further. In our theory of NAES, while we find that it provides means for sustainable intensification, we rely on the idea of sharing. As the human impact reaches all ecosystems in the biosphere, it is best to learn to live decently with our fellow species. With this thinking, the focus is on adjusting the intensity to ecological sustainability. For industrial, input intensive farming, this would mean lowering the intensity and even lowering productivity per unit land area for increasing productivity per unit other inputs, including biological diversity. In subsistence farming, in which the insufficiency of sustainable inputs, e.g., recycling fertilizers, coupled with a high rate of population growth often results in land degradation, there is space for agroecological intensification (Pretty et al., 2006). In terms of sufficiency, what is enough must not exceed what is too much for the ecosystems that the human species shares with other species, both presently and in the future.

In the NAES thinking, agroecological contextualization brings a geographical dimension to sufficiency. What is sufficient in what place? NAES food systems would favor adapting diets to local ecological provisioning and limits (knowing that such an adaptive arrangement might not be politically achievable). This would ease the burden of the (still missing) global food governance in holding back the pressures that created the present commodified, agro-industrial system, which lacks inherent control other than destruction of land as a result of overexploitation. The idea of a food community in NAES implies participation by those who eat. Even though food production is localized (i.e., relying on local integrated nutrient recycling and energy production, local feeds in livestock production, and local food processing), food is exported from NAESs to other regions and also globally. Participatory governance by the food community should reach the production systems of origin of the exotic foods alike. Philosophically, these exotic foods may be geographically imported, but still not imported from outside of the NAES food community.

Another diet related aspect of sufficiency is the share of exotic, imported foods. In many cases, local food production could provide foods with the same function. For example, in the Nordic countries several berries, as horticultural or non-wood forest products, are available to anyone willing to pick them. 
Reengaging with locally available foods would reduce the need of importing exotic fruits and berries. In the NAES thinking, local products rather than imported ones would add value, as the production system and its possible externalities would be internalized. Rather than merely seeing added value in local production, the efficient utilization of locally available resources should be seen as a value choice. The composition of diet is a sensitive cultural issue, but prone to value-driven changes.

Some of the material flows in the industrial systems are incompatible with sustainability (Huber, 2000). This also applies to current food systems. This incompatibility is related to land use, food consumption, and inputs used in food production. From the land use perspective, food production must be compatible with the supply of other ecosystems services. For example, in peat lands the cultivation of annual crops produces greenhouse gas emissions in quantities substantially higher than use of these lands for perennial leys (Maljanen et al., 2007). In the NAES model, these peatlands would be used, for example, to produce grass to feed cattle or as a feedstock for biogas production instead of cereal production. In the NAES thinking, land use should not be incompatible with sustainability, but rather adapted to growing biomass that is suitable to that specific agroecosystem.

Material flows are currently largely based on non-renewable resources (Haas et al., 2015). In the conventional food chains, agriculture relies heavily on external inputs such as mineral fertilizers and fossil energy. Many of these flows are related to intensive livestock production. This has created a need for massive biomass imports to feed cattle resulting in nutrient concentrations in livestock farms (Buckwell and Nadeu, 2016; Uwizeye et al., 2016; Spiegal et al., 2020). Food production that is so heavily relying on inputs from non-renewable resources is not compatible with sustainability. As such, this leads to the fundamental principle that sustainable food systems must be based on use and maintenance of renewable resources.

\section{Consistency of NAES}

In Huber's (2000) framing, consistency relates to the production processes in a system and their ecological functioning in support of the development of balance and compatibility between the natural and industrial metabolisms of the system in question. It should be noted that while Huber (2000) does not make a direct reference to Marx's concept of metabolic rift, the balance between the industrial and ecological metabolisms is in line with the academic work which revolves around healing the metabolic rift (Schneider and McMichael, 2010). The NAES model speaks to Huber's conceptualization of consistency through its development and implementation of new systems level materials flows, which serve to change the underlying qualities of the industrial ecology of the agricultural system, and the food system based on NAES. The innovative material flows in the NAES model are fundamentally aimed at the sustainable transformation of the overarching system, rather than simply minimizing the impacts of the traditional material flows within industrial farming. Within the NAES model the focus remains on integrated environmental solutions, rather than piecemeal solutions or a focus on solely downstream remediation measures.
We argue that NAES is consistent with the goal of circularity, as each AES in it is designed to recycle, and within the network, the AESs can co-operate in recycling.

The aim of NAES is not to mimic a natural ecosystem, as it remains a food production and processing system that does require inputs and produces outputs. However, it does bring the industrial and natural ecology into a more harmonious metabolism by respecting and working with the biophysical and socio-cultural realities of each individual place. In addition, the NAES model is not a top down or rigid interpretation of what constitutes a sustainable agricultural system. Rather, it is a cocreative model focused on utilizing the creativity and motivation of the people participating in the discrete system. Too often system models are designed in the academic or policy sphere with not enough deference to the challenges faced on the ground. The NAES model overcomes this problem through its flexible approach to the goal of creating local and regional food systems. An important aspect of the consistency strategy is to foster an innovation process that utilizes the productive capacity and creativity of modern society (Huber, 2000). We interpret the role of co-creation as an expression of citizen science, which fills this facet of consistency. In the next sections we will discuss the role of non-academic participants in the design and implementation of the pilot AES and the subsequent expansion to the NAES concept.

While Huber (2000) refers to consistency within environmental sustainability, any suggested transformative food system needs to meet with wider sustainability goals. A framework through which integrated solutions are accessible and widely understood are the Sustainable Development Goals (SDGs) of the United Nations (UN, 2015). Each of the goals represents an approach to sustainability that transcends siloed approaches and seeks for holistic solutions to the wicked problems which are a barrier to transition (Rittel and Webber, 1973). We agree with the caution raised by Randers et al. (2018), and with their concern that the socio-economic goals in the SDGs are not compatible with the aim of not exceeding planetary boundaries. We find that the NAES approach to food systems is consistent with the idea underlying the SDGs, given that the socio-economic goals need to be consistent with the environmental goals, and that the systems operate within the planetary boundaries.

\section{CO-CREATION IN DEVELOPING THE AES AND NAES CONCEPTS}

Bringing industrial symbiosis to the food production arena creates some additional challenges and opportunities. The AES model asks not only for a transformation in spatially detached production systems, but a redevelopment of the physical spaces where the involved entrepreneurs live and produce food. This is because one feature of involving farms is that they often serve a dual purpose of being production spaces, but also human spaces where people live within the landscapes. All the farms in the pilot project were homes as well as being productive spaces. This dual use of the land requires a fundamental buy-in from the people that live within the symbiosis, this is one of the reasons 
why the co-creative model and the involvement of the farmbased entrepreneurs was so fundamental to our development of the AES and NAES concepts. For the food processing partners in an AES, the mental step is different, but equally big. In the present system, the agricultural products which they use to make food products are commodities from the general market, and location of their processing plants is not dependent on where these commodities are produced. In an AES, the food processor with their processing plant comes physically to the location of the agroecosystem.

\section{Co-creation in the Palopuro Pilot Project}

The term agroecological symbiosis (AES) was first used in the development of a redesigned production system in Palopuro village, Finland (Koppelmäki et al., 2016; Helenius et al., 2017). The co-creation process was integral to the Palopuro case and the expansion of AES into the NAES concept. The entrepreneurs in Palopuro came together naturally to figure out a model for integrating their operations for mutual benefit. This was a result of their everyday interaction and shared goals for the development of their respective businesses. At the start of the co-creative endeavor there were three farmers based in Palopuro village and a bakery owner from the Helsinki capital region. An energy company, represented by its CEO, joined at a later date. It was these entrepreneurs who developed the first proposal for what this cooperation might look like in practice and the entrepreneurs contacted the scientists at the University of Helsinki to assist with moving from idea to practice. The entrepreneurs and other transdisciplinary actors such as, civil servants from the relevant municipality and the ministries served as transformative agents in this project and were active in asking the scientific participants to investigate issues that were pertinent to their community (Shirk et al., 2012).

In practice this project would not exist without the cooperation from both the academic and non-academic actors. Both types of knowledge were needed to identify the problems and solutions that went into designing the pilot project AES. It should be noted that the farmers and the other entrepreneur actors at the heart of the pilot had a base motivation of improving the livelihood of their lived environment. They were the initiators of the transformative process. The farms and the bakery were already practicing organic production when the pilot project was planned. Alternative production methods when implemented in isolation, like organic production, do not change the entrepreneurs' position in the food systems. In that sense the substantial change from the actors' perspective is re-designing the roles of the actors and their respective agency within the food systems.

The entrepreneurs played a key role as food system innovators. A grain farmer living in Palopuro led the charge to develop a redesigned food and farming system as he was not happy in being an anonymous supplier to the industrialized grain supply chain, serving equally anonymous consumers. The development of the AES model could be characterized as taking back agency over the functioning of the local food system. This collaboration was also born in the idea of being able to add value to the grain produced, when sharing with other farmers the problem of increasing price margin between farm price of the grain agricultural products and price of food in the market for the consumers. This general phenomena in the commodity chain means decreasing share to farmers, and is the main cause of loss of farm income (Peltoniemi and Niemi, 2016). For example, the grain farmer saw that a shift from solely supplying a raw commodity to the grain food chain, to producing an added value local product with the bakery serves as insurance against the ups and downs of the global grain market. While there also was an economic aspect to the development of this idea, focusing solely on the economic component does not capture the scope of the motivation. There were considerations that extended beyond the financial, including quality of life and the development and maintenance of a vibrant local community.

Additionally, in the co-creation of the AES model the producers sought for an avenue to step back from the fossilbased industrialized food system. After listening to the goals of the entrepreneurs in Palopuro, it was relatively straightforward for us as scientists to match their vision to the concept of a circular, localized bioeconomy. For example, our previous theoretical work on producing biogas from nitrogen fixing leys and using the digestate as recycling fertilizer (Tuomisto and Helenius, 2008) matched perfectly to the case. Neither farm scale biogas production or localized small scale food processing were novel ideas [for farm-scale biogas in the Nordic context see Berglund and Börjesson (2006); Raven and Gregersen (2007); Ahlberg-Eliasson et al. (2017)]; rather, what is unique in AES, it is the combination of existing ideas to develop a symbiosis that explicitly addresses several facets of sustainability.

Existing spatial and social connections significantly lowered some potential barriers to this co-creative collaboration. The academic aspect of the co-creative endeavor served to support the actualization of the initial ideas of the entrepreneurs, rather than directing the project. Thus, the initial motivation and design ideas came from the bottom-up and were led by the persons in place. This helped in developing ideas that were appropriate for the place and people that would be implementing these ideas in practices. There was a mutual decision to apply for public funding to further explore the validity and feasibility of the proposed system, which led to the development of the Palopuro AES pilot project. It should be noted that the name agroecological symbiosis itself was coined by a policy actor who was invited into the grant writing process as an advisor. The inclusion of policy actors, for example from the municipal and ministerial level, was an important step in actualizing the pilot project as they were integral to accessing the funding mechanisms that made the implementation possible.

In discussions of food system change there is a focus on consumer behavior, usually centered around on what consumers do and do not buy (for e.g., Kneafsey et al., 2008). Understanding this dynamic is important; however, the role of consumer behavior alone is not enough for systems level change, as the farmer and the food processor must be willing to participate in a system that steps back from the conventional system long before the food reaches the consumer. The role of farmer-level and food processor level buy-in is vitally important for designing contextually appropriate and actionable food systems. It is very 
difficult for policy players and other non-farm-based actors to design a place-based model to support food system redesign as if place-based, the food systems are intimately tied to the context of the individual place where they operate (Murdoch et al., 2000; Feagan, 2007; Woods, 2012). In addition, the dual role as farmers and residents of the physical space of the food system gave the farming partners in the symbiosis a unique insight into what would work for their iteration of the AES.

There were parallel goals in the AES pilot of designing a sustainability-based production and processing model and revitalizing the surrounding rural area. In the face of other sociospatial changes in the area, opening a social space on the farm through the farm market and other activities filled a void in the fabric of the Palopuro community, as many of the publicly accessible social spaces in the area were defunct. The opening of social spaces within the production landscape of the farm served the function of bringing the "people who eat" quite literally to the farm. Please note that the widely used term "consumers" does not fully capture the range of roles that play out in a food system based on the principles of agroecology, however, for the sake of clarity we will continue to use this term in this paper as needed.

Bringing non-farming actors into the food system in the AES pilot project served to lessen the distance between producers and consumers, both physically and mentally. It served in building the consumer side of the food community within the AES. The farmers of Palopuro AES specifically wanted their farms to be more than remote places, they wanted their farms to be more accessible, shared space where citizens can get in touch with their local food system. One of the goals in bringing the consumer participants to the farm was exposing functions of the food system that are not in the realm of the consumer experience in an industrialized food chain. For example, the baker was excited about the possibility of making concretely visible to the consumers how the grain flows from the farm to the bakery and is turned to bread through the use of transparent piping in a production area that was visible to visitors.

This acquaintance takes place on multiple levels, both through a growing familiarity with the process of turning raw materials into retail food products and developing one-on-one social ties with their local farmers and food processors. The farmers and food processors are a central feature in the farm markets held in the farmyard of the grain farm in Palopuro. In addition to the strictly food system-based participants, these markets also support the participation of other types of food retailers and local craftspeople. Creating a consistent space where these various types of local makers could come together allowed the farm to serve as a point of connection where social relationships were formed, and information was shared. In addition to the farm markets, the social space has also served as an education space for information exchange hosting numerous visits of other farmers, academics, and policy players to learn about the AES model and share their own experiences in redesigning local food systems. Creating platforms for this level of knowledge exchange supports the ethos of continuing opportunities to engage in citizen science (Ryan et al., 2018).

The way in which the scientific and non-scientific participants came together was both co-creative and contractual, as the members of the community in question were the drivers in identifying the key themes pertinent for their community (Shirk et al., 2012). For example, the food producers and processors decided that they wanted to change their positioning within the food system, rather than an entity outside the community indicating that there should be a change to serve a broader purpose. The level of buy-in in the pilot project was high, this most likely a result of the core ideas emanating from the participants themselves. "Science" in isolation can design a tight and interesting model, but if it is not functional for the people who aim to live with it, then ultimately it will not work in practice (Poulsen et al., 2014). The Palopuro AES has been a grassroots effort, rather than an innovation that came from the top down. While there were scientists involved in the process from very early on, they came to the table on an equal footing as the entrepreneurs. There were multiple forms of knowledge explored and respected in the formation of the AES model. Both the AES idea, the pilot AES, and to a lesser degree the subsequent networks extension for a food system model, are manifestations of citizen science in action. Regular people in place working with scientists to design a food production and processes system that served to improve the local foodscape, while fostering sustainability and livelihoods. Citizen science and knowledge co-production are the vital links between designing a sustainable food system in theory and practice (Poulsen et al., 2014).

\section{Co-creation in the NAES Concept}

The successful collaboration over the AES pilot project laid the ground for the continued co-creation of knowledge that has led to the expanded concept of NAES. It should be noted that both these concepts support the development of placed-based food systems that are biophysically, socially, and culturally appropriate for the area where they operate (Feagan, 2007; Woods, 2012). Having the entrepreneurs as the initial drivers of this relocalization driven transformation of the food system was vital to creating a robust buy-in to the project. In addition, by bringing many different types of actors to the table, each actor was able to lean into their strengths and expertise. This aided in bringing the system from initial concept to functioning pilot in a relatively short period of time.

The NAES concept builds on the AES concept by proposing networks of AES forming the production-processing foundation for transformative change from food chain to sustainability. The continued development of the more generalized food system model moved beyond the direct work with the on the ground actors. The extension from AES to NAES, which addresses a higher system level, made it obvious that new stakeholder groups must be included in the co-creating process. We are working on this in our current project, "Eco-Industrial Symbioses for Food Production Chain-Feasibility for SouthSavo" (2020-2021, Regional Council of South-Savo, Finland). We aim to engage key people representing regional administration, policymakers, marketing channels, food processing companies, and action groups among farmers committed to the creation process. Redesigning a food system beyond the local level is an endeavor that requires a range of actors, including those 
close or within the existing system to be able to accurately reflect the reality on the ground. It is necessary to have a sufficiently deep level of co-creation between the stakeholders to achieve systemic transformation. Transformative change is more than simply societal intervention, requires co-creation beyond citizen science, and involves contributions from, to, and between the micro, meso, and macro levels (Schäfer and Kieslinger, 2016). Our experience encourages such an endeavor even if enabling policies are not (yet) there. This is because scientists as public servants may rather underestimate than fully appreciate and tap to the skills, enthusiasm, and ability of, especially, the entrepreneurs to creatively solve any emerging challenges as they appear. The scientists' role becomes one of process facilitators, especially in regard to analytically crosschecking the system model proposal against sustainability criteria (Horlings et al., 2020).

A system can be co-creative, yet still very linear and conventional in its manifestation. The motivation of the producers and processors revolves most directly around the economic sphere; an AES must ultimately allow the entrepreneurs to maintain, with a prospect of improving, a livelihood while making commitments to participate. For cocreating a NAES, it is important to find further support for maintenance and improvement of the livelihoods through the network. The scientific actors are more directly able to keep the detailed environmental and wider sustainability goals in mind and at play within the development of the system, while the non-academic actors are able to keep track of what is functional within their community. The co-creation is not about just different groups reporting what they want. Rather it is activation, enthusiasm, and personal involvement of the parties at each level-producers, policy players, science practitioners, and the citizenry-all working together in the interest of sustainability and local food.

\section{CONCLUDING REMARKS}

In this paper, we argued how rearranging farming, food processing, and energy systems to follow the concept of AES would result in a shift to sustainable food production at systems level. Such a transformative change would require networks of AES, NAES, which would serve as the foundation of an emerging agroecology-based, geographically, and culturally contextualized food systems. We propose NAES as a generic principle for a transformative change in food systems toward sustainability. The NAES concept offers a systems-level alternative to the industrial and globalized food chains. NAES are distributed rather than consolidated, and entrepreneurial rather than centralized agribusiness. NAES based food systems are adaptive and resilient, ecologically more efficient, inherently more sufficient, and more consistent with sustainability goals than the present conventional agribusiness-based food chains. We argue that food systems based on NAES grids are able to produce enough food for a healthy diet at the local level. This may require deintensification of farming systems in some regions, while intensifying food production in other regions. The NAES food system(s), like any other system, is explicitly not proposed for "feeding" any population at any cost; rather, we propose NAES for a transformative change in which the population times diet times sustainability equation is explicit.

The AES model supports agency for the participating farmers, food processors, and energy producers engaged in developing place-based food production systems. At the wider system level, the NAES invites the food market and the people who eat the food from the NAES to participate in forming a food community, and in regaining an agroecosystem-based sense of food.

There are benefits to the system from a biophysical and sociocultural perspective. As the AES and NAES, represent a circular bioeconomy, that runs on-and even in some cases can produce in excess-renewable bioenergy, the obvious environmental benefits include plant nutrient recycling and balanced nutrient flows, as well as unforeseen climate efficiency. We have not yet quantified the carbon sinks or offsets of emissions from our pilot AES to give an example. This needs to be done. Diversification of agricultural land use gives some benefits to biodiversity, but further guidelines need to be developed, following the principle of land sharing. An obvious danger is biofuel production supplanting food production; in the AES concept, the biofuel production is integrated to, and primarily serves the primary production, processing, and delivery of the food that the AES produces.

From a social perspective there are benefits for the entrepreneurs through their direct involvement in the cocreation of the NAES. These include creating sustainable and viable livelihoods in place, while creating a food and energy infrastructure that supports a robust local food system. Under the NAES model both farming, and food processing can move away from the fossil-fuel based, industrial model. In addition, the producers are more able to develop food systems that speak to their own needs, rather than being solely at the mercy of the globalized market. In addition, the NAES concept allows for the potential of community development in the rural spaces as evidenced by the use of the social space in the AES pilot project.

We based our concept development on co-creation of the first pilot AES, the Palopuro symbiosis (in Hyvinkää, Finland). It cannot serve as a universal model, rather we used it to propose design principles and a system vision.

We have not studied the issues of the food market. For example, how to best organize the purchasing procedures for the distributed food production. We have no direct evidence of the higher (environmental and social) value of the products mirrored in the relative prices, compared to products from the conventional chains. How to meet the challenge of the food processing tending to industrialize and consolidate, rather than stay entrepreneurial at small and medium scales? We are aware that the bulk of food presently originates in only a small number of food industry giants. For the NAES model to be realized, it might be essential to get the present consolidated industries to get involved, and their production distributed to emerging NAESs. This requires a new business model for the industry. However, the Palopuro symbiosis grew from a grassroots effort, 
thus it appears that there is space for entrepreneurial food producers to initiate AESs and facilitate formation of NAESs. NAES based food systems seem to be able to grow parallel to, although competing with, complementary to the conventional consolidated chains.

Finally, based on our experiences in developing the Palopuro AES pilot project, we conclude that co-creation is a productive and rewarding, if not essential mode of research for systemic transformations in the food sector. The farmers, the food processors, and the associated energy producers, as entrepreneurs, have the knowledge, the motivation and the vision for improving not only their own businesses, but especially, their lives and the livelihoods of their clientele, and their social communities. Our experience reflects the importance of reciprocity between non-science actors and scientists in the development of the AES model. There is an added value from an increase in buy-in from non-scientific actors that are invited and welcomed to the innovation process works in favor of sustainability transformation. However, it should be emphasized that the non-science actors welcoming the scientists into the space was highly important to the success of the project. The bottom-up design of the AES pilot served to build a foundation and is an important facet in developing place-based food systems redesign. The AES and by extension the NAES model are dependent on the local and context-based knowledge that the food systems entrepreneurs brought to the discussion. A robust localized food system cannot be designed by scientists and policy actors alone, it must be inclusive of the non-science actors living and working within that system. Based on the experiences we had in the co-creation of the Palopuro symbiosis, we find that there is a huge potential in tapping into co-creation as a method for transforming the food system.

\section{DATA AVAILABILITY STATEMENT}

The original contributions presented in the study are included in the article. Further inquiries can be directed to the corresponding author/s.

\section{REFERENCES}

Ahlberg-Eliasson, K., Nadeau, E., Levén, L., and Schnürer, A. (2017). Production efficiency of Swedish farm-scale biogas plants. Biomass Bioener. 97, 27-37. doi: 10.1016/j.biombioe.2016.12.002

Berglund, M., and Börjesson, P. (2006). Assessment of energy performance in the life-cycle of biogas production. Biomass Bioener. 30, 254-266. doi: 10.1016/j.biombioe.2005.11.011

Bowen, S. (2011). The importance of place: re-territorialising embeddedness. Soc. Rural. 51, 325-348. doi: 10.1111/j.1467-9523.2011.00543.x

Buckwell, A., and Nadeu, E. (2016). Nutrient Recovery and Reuse (NRR) in European Agriculture. A Review of the Issues, Opportunities, and Actions. Brussels: RISE Foundation. Available online at: https://risefoundation.eu/ wp-content/uploads/2020/07/2016_RISE_NRR_Full_EN.pdf (accessed July 31, 2020).

Campbell, B. M., Beare, D. J., Bennett, E. M., Hall-Spencer, J. M., Ingram, J. S., Jaramillo, F., et al. (2017). Agriculture production as a major

\section{AUTHOR CONTRIBUTIONS}

SH-A contributed by reviewing, editing and writing the consistency, and co-creation sections. KK contributed reviewing, editing and writing the efficiency, and sufficiency sections. KK also is a farmer in Palopuro symbiosis, which was to the benefit of the co-creation process. $\mathrm{KK}$ and $\mathrm{JH}$ contributed to the original biophysical AES model development, with the entrepreneurs since 2015, in the context of Palopuro symbiosis. SH-A has also been working with the AES concept and the pilot case since 2015, specifically looking at the social dimensions and implications of a relocalized food system. SH-A did the formatting for the article. All authors contributed to the article and approved the submitted version.

\section{FUNDING}

This research was funded by the Ministry of Environment YM52/481/2015 and YM73/481/2017 grants, by SouthSavo Regional Council Grant No. EURA2014/7916/09 02 01 01/2019/ESAVO, Cities Mikkeli and Kouvola (Finland) and Mikkeli University Consortium's MUC Funding for position of research director on sustainable transformation in food systems, Ruralia Institute, University of Helsinki.

\section{ACKNOWLEDGMENTS}

We are most grateful to our co-creating partners in Palopuro symbiosis, Markus Eerola, Peter Zukale, and Jukka Kivelä. We are grateful for invaluable contributions from representatives of the administration Tarja Haaranen and Marja-Liisa Tapio-Biström. We would like to extend our warm thanks to our research colleagues in our AES and NAES projects, especially to Suanna Kujala, Tuure Parviainen, Ari-Matti Seppänen, Elina Virkkunen, and Erika Winquist. We would like to extend a special thank you to Janne Salovaara for assisting us with digitizing the figures for this publication. In addition, we would like to thank our peer reviewers and special edition editor for their insightful comments and suggestions that helped us to improve our article.

driver of the earth system exceeding planetary boundaries. Ecol. Soc. 22:8. doi: 10.5751/ES-09595-220408

Chertow, M., and Ehrenfeld, J. (2012). Organizing self-organizing systems: Toward a theory of industrial symbiosis. J. Ind. Ecol. 16, 13-27. doi: 10.1111/j.1530-9290.2011.00450.x

Chertow, M. R. (2000). Industrial symbiosis: literature and taxonomy. Ann. Rev. Ener. Environ. 25, 313-337. Available online at: https://pdfs. semanticscholar.org/1a5f/dc68ba3eb4a8b61e2237401a8b0a813bb693.pdf doi: 10.1146/annurev.energy.25.1.313

Clapp, J. (2016). Food, 2nd Edn. London: Polity Press.

Comberti, C., Thornton, T. F., Wyllie de Echeverria, V., and Patterson, T. (2015). Ecosystem services or services to ecosystems? Valuing cultivation and reciprocal relationships between humans and ecosystems. Glob. Environ. Change 34, 247-262. doi: 10.1016/j.gloenvcha.2015.07.007

Condon, P. M., Mullinix, K., Fallick, A., and Harcourt, M. (2010). Agriculture on the edge: strategies to abate urban encroachment on to agricultural lands by promoting viable human-scale agriculture as an integral element 
of urbanization. Int. J. Agric. Sustain. 8, 104-115. doi: 10.3763/ijas.20 09.0465

Connor, D. J. (2013). Organically grown crops do not a cropping system make and nor can organic agriculture nearly feed the world. Field Crops Res. 144, 145-147. doi: 10.1016/j.fcr.2012.12.013

Cresswell, T. (2013). Place: A Short Introduction. Hoboken, NY: John Wiley \& Sons.

Crist, E., Mora, C., and Engelman, R. (2017). The interaction of human population, food production, and biodiversity protection. Science 356, 260-264. doi: $10.1126 /$ science.aal2011

De Shutter, O. (2010). Report Submitted by the Special Rapporteur on the Right to Food. United Nations General Assembly A/HRC/16/49. Available online at: https://www2.ohchr.org/english/issues/food/docs/A-HRC-16-49.pdf (accessed July 31,2020 ).

Diercks, G., Larsen, H., and Steward, F. (2019). Transformative innovation policy: addressing variety in an emerging policy paradigm. Res. Policy 48, 880-894. doi: 10.1016/j.respol.2018.10.028

Dorninger, C., Abson, D. J., Fischer, J., and von Wehrden, H. (2017). Assessing sustainable biophysical human-nature connectedness at regional scales. Environ. Res. Lett. 12:055001. doi: 10.1088/1748-9326/aa68a5

Ellen MacArthur Foundation (2019). Cities and Circular Economy for Food. Available online at: www.ellenmacarthurfoundation.org (accessed on 01 July 2020).

EU (2020). Quality Schemes Explained. European Commission. Online: Available online at: https://ec.europa.eu/info/food-farming-fisheries/food-safety-andquality/certification/quality-labels/quality-schemes-explained_en (accessed on 20 July 2020).

Eyhorn, F., Muller, A., Reganold, J. P., Frison, E., Herren, H. R., Luttikholt, L., et al. (2019). Sustainability in global agriculture driven by organic farming. Nat. Sust. 2, 253-255. doi: 10.1038/s41893-019-0266-6

FAO (2018a). Transforming Food and Agriculture to Achieve the SDGs. 20 Interconnected Actions to Guide Decision-Makers. Rome: Food and Agriculture Organization of the United Nations. Available online at: http://www.fao.org/3/ I9900EN/i9900en.pdf

FAO (2018b). The 10 Elements of Agroecology. Guiding the Transition to Sustainable Food and Agricultural Systems. Rome: Food and Agriculture Organization of the United Nations. Available online at: http://www.fao.org/3/i9037en/i9037en. pdf

Feagan, R. (2007). The place of food: mapping out the 'local' in local food systems. Progr. Human Geogr. 31, 23-42. doi: 10.1177/0309132507073527

Foley, J. A., Ramankutty, N., Brauman, K. A., Cassidy, E. S., Gerber, J. S., Johnston, M., et al. (2011). Solutions for a cultivated planet. Nature 478, 337-342. doi: 10.1038/nature10452

Foster, J. B. (1999). Marx's theory of metabolic rift: classical foundations for environmental sociology. Am. J. Sociol. 105, 366-405. doi: 10.1086/210315

Francis, C., Lieblein, G., Gliessman, S., Breland, T. A., Creamer, N., Harwood, R., et al. (2003). Agroecology: the ecology of food systems. J. Sust. Agric. 22, 99-118. doi: 10.1300/J064v22n03_10

Frosch, R. A., and Gallopoulos, N. E. (1989). Strategies for manufacturing. Sci. Am. 261, 144-152. doi: 10.1038/scientificamerican0989-144

Garnett, T., Röös, E., and Little, D. C. (2015). Lean, Green, Mean, Obscene? What is Efficiency? And is it Sustainable? Animal Production and Consumption Reconsidered. Oxford: Food Climate Research Network (FCRN).

Geels, F. W., and Schot, J. (2007). Typology of sociotechnical transition pathways. Res. Policy 36, 399-417. doi: 10.1016/j.respol.2007.01.003

Graedel, T. E., and Allenby, B. R. (2010). Industrial Ecology and Sustainable Engineering: International Edition. London: Pearson Education.

Haas, W., Krausmann, F., Wiedenhofer, D., and Heinz, M. (2015). How circular is the global economy? An assessment of material flows, waste production, and recycling in the European union and the world in 2005. J. Industr. Ecol. 19, 765-777. doi: 10.1111/jiec.12244

Heikkurinen, P., Young, C. W., and Morgan, E. (2019). Business for sustainable change: extending eco-efficiency and eco-sufficiency strategies to consumers. J. Clean. Product. 218, 656-664. doi: 10.1016/j.jclepro.201 9.02.053

Helenius, J., Koppelmäki, K., and Virkkunen, E (eds.). (2017). Agroecological Symbiosis in Nutrient and Energy Self-Sufficient Food Production. Reports of the Ministry of the Environment 18/2017. Available online at: http://urn.fi/URN: ISBN:978-952-11-4716-6
Helenius, J., Wezel, A., and Francis, C. A. (2019). "Agroecology," in Oxford Research Encyclopedia of Environmental Science, ed H. H. Shugart (Oxford: Oxford University Press). doi: 10.1093/acrefore/9780199389414.013.297

Hooper, D. U., Chapin, I. I. I., F. S., Ewel, J. J., Hector, A., Inchausti, P., et al. (2005). Effects of biodiversity on ecosystem functioning: a consensus of current knowledge. Ecol. Monogr. 75, 3-35. doi: 10.1890/04-0922

Horlings, L. G., Nieto-Romero, M., Pisters, S., and Soini, K. (2020). Operationalising transformative sustainability science through placebased research: the role of researchers. Sust. Sci. 15, 467-484. doi: 10.1007/s11625-019-00757-x

Huber, J. (2000). Towards industrial ecology: sustainable development as a concept of ecological modernization. J. Environ. Policy Plan. 2, 269-285. doi: 10.1080/714038561

Hukkinen, J. (2001). Eco-efficiency as abandonment of nature. Ecol. Econ. 38, 311-315. doi: 10.1016/S0921-8009(01)00217-8

IPCC (2019). IPCC Special Report On Climate Change, Desertification, Land Degradation, Sustainable Land Management, Food Security, And Greenhouse Gas Fluxes in Terrestrial Ecosystems. Special Report Climate Change and Land, Intergovernmental Panel on Climate Change. Available online at: https://www. ipcc.ch/srccl/

IPES-Food (2016). From Uniformity to Diversity: A Paradigm Shift From Industrial Agriculture to Diversified Agroecological Systems. Louvain-la-Neuve: International Panel of Experts on Sustainable Food Systems. Available online at: http://www.ipes-food.org/_img/upload/files/UniformityToDiversity_ FULL.pdf

IPES-Food (2017). Too Big to Feed: Exploring the Impacts of Mega-Mergers, Concentration, Concentration of Power in the Agri-Food Sector. Louvain-laNeuve: International Panel of Experts on Sustainable Food Systems. Available online at: http://www.ipes-food.org/_img/upload/files/Concentration FullReport.pdf

IPES-Food (2018). Breaking Away From Industrial Food and Farming Systems: Seven Case Studies of Agroecological Transition. Louvain-la-Neuve: International Panel of Experts on Sustainable Food Systems. Available online at: http://www.ipes-food.org/_img/upload/files/CS2_web.pdf

Jongman, R. H. (2002). Homogenisation and fragmentation of the European landscape: ecological consequences and solutions. Landscape and Urban Plan. 58, 211-221. doi: 10.1016/S0169-2046(01)00222-5

Kastner, T., Ibarrola Rivas, M. J., Koch, W., and Nonhebel, S. (2012). Global changes in diets and the consequences for land requirements for food. Proc. Natl. Acad. Sci. U.S.A. 109, 6868-6872. doi: 10.1073/pnas.1117 054109

Keune, H., Dendoncker, N., Popa, F., Sander, J., Kampelmann, S., Boeraeve, F., et al. (2015). Emerging ecosystem services governance issues in the Belgium ecosystem services community of practice. Ecosyst. Serv. 16, 212-219. doi: 10.1016/j.ecoser.2015.06.001

Khoury, C. K., Bjorkman, A. D., Dempewolf, H., Ramirez-Villegas, J., Guarino, L., Jarvis, A., et al. (2014). Increasing homogeneity in global food supplies and the implications for food security. Proc. Natl. Acad. Sci. U.S.A. 111, 4001-4006. doi: 10.1073/pnas.1313490111

Kloppenburg, J., Hendrickson, J., and Stevenson, G. W. (1996). Coming into the foodshed. Agricult. Human Values 13, 33-42. doi: 10.1007/BF01538225

Kneafsey, M., Cox, R., Holloway, L., Dowler, E., Venn, L., and Tuomainen, H. (2008). Reconnecting Consumers, Producers and Food: Exploring Alternatives. Oxford: Bloomsbury Publishing.

Koppelmäki, K., Eerola, M., Albov, S., Kivelä, J., Helenius, J., Winquist, E., et al. (2016). "Palopuro Agroecological Symbiosis". A pilot case study on local sustainable food and farming (Finland)," in Challenges for the New Rurality in a Changing World, Vol. 12, eds P. Rytkönen and U. Hård (COMREC Studies in Environment and Development), 171-172. Available online at: http://sh.divaportal.org/smash/get/diva2:956067/FULLTEXT01.pdf

Koppelmäki, K., Helenius, J., and Schulte, R. P. O. (2021). Nested circularity in food systems: a NORDIC case study on connecting biomass, nutrient and energy flows from field scale to continent. Resour. Conserv. Recycl. 164:105218. doi: 10.1016/j.resconrec.2020.105218

Koppelmäki, K., Parviainen, T., Virkkunen, E., Winquist, E., Schulte, R. P., and Helenius, J. (2019). Ecological intensification by integrating biogas production into nutrient cycling: modeling the case of agroecological symbiosis. Agric. Syst. 170, 39-48. doi: 10.1016/j.agsy.2018.12.007 
Lang, T., and Heasman, M. (2004). Food Wars: The Global Battle for Mouths, Minds and Markets. London: Earthscan.

Loos, J., and von Wehrden, H. (2018). Beyond biodiversity conservation: land sharing constitutes sustainable agriculture in European cultural landscapes. Sustainability 10:1395. doi: 10.3390/su10051395

Maljanen, M., Hytönen, J., Mäkiranta, P., Alm, J., Minkkinen, K., Laine, J., et al. (2007). Greenhouse gas emissions from cultivated and abandoned organic croplands in Finland. Boreal Environ. Res. 12, 133-140. Available online at: http://www.borenv.net/BER/archive/pdfs/ber12/ber12-133.pdf

Marsden, T., and Sonnino, R. (2012). Human health and wellbeing and the sustainability of urban-regional food systems. Curr. Opin. Environ. Sust. 4, 427-430. doi: 10.1016/j.cosust.2012.09.004

Monteleone, M. (2015). "Reshaping agriculture toward a transition to a post-fossil bioeconomy," in Law and Agroecology, eds M. Monteduro, P. Buongiorno, S. Di Benedetto, A. Isoni (Heidelberg: Springer), 359-376.

Murdoch, J., Marsden, T., and Banks, J. (2000). Quality, nature, and embeddedness: Some theoretical considerations in the context of the food sector. Econo. Geogr. 76, 107-125. doi: 10.2307/144549

Oskamp, S. (1995). Applying social psychology to avoid ecological disaster. J. Soc. Issu. 51, 217-239. doi: 10.1111/j.1540-4560.1995.tb01356.x

Owen, L., Udall, D., Franklin, A., and Kneafsey, M. (2020). Place-based pathways to sustainability: exploring alignment between geographical indications and the concept of agroecology territories in wales. Sustainability 12:4890. doi: $10.3390 /$ su12124890

Parviainen, T., and Helenius, J. (2020). Trade imports increasingly contribute to plant nutrient inputs: case of the finnish food system 1996-2014. Sustainability 12:702. doi: $10.3390 /$ su12020702

Patel, R. (2009). Food sovereignty. J. Peas. Stud. 36, 663-706. doi: $10.1080 / 03066150903143079$

Patel, R., and Moore, J. W. (2017). A history of the world in seven cheap things: a guide to capitalism, nature, and the future of the planet. Berkeley, CA: University of California Press.

Peltoniemi, A., and Niemi, J. (2016). Price margins in the finnish food chain. Proc. Syst. Dynam. Innovat. Food Netw. 2016, 116-121. doi: 10.18461/pfsd.2016.1615

Pereira, L. M., Drimie, S., Maciejewski, K., Bon Tonissen, P., and Biggs, R. (2020). Food system transformation: Integrating a political-economy and social-ecological approach to regime shifts. Int. J. Environ. Res. Public Health 17:1313. doi: 10.3390/ijerph17041313

Pimbert, M. (2009). Towards Food Sovereignty. London: International Institute for Environment and Development.

Poulsen, M. N., Spiker, M. L., and Winch, P. J. (2014). Conceptualizing community buy-in and its application to urban farming. J. Agric. Food Syst. Commu. Dev. 5, 161-178. doi: 10.5304/jafscd.2014.051.014

Pretty, J. N., Noble, A. D., Bossio, D., Dixon, J., Hine, R. E., Penning de Vries, F. W. $\mathrm{T}$., et al. (2006). Resource-conserving agriculture increases yields in developing countries. Environ. Sci. Technol. 40, 1114-1119. doi: 10.1021/es051670d

Quaye, W., Jongerden, J., Essegbey, G., and Ruivenkamp, G. (2010). Globalization vs. localization: global food challenges and local solutions. Int. J. Consum. Stud. 34, 357-366. doi: 10.1111/j.1470-6431.2010.00868.x

Randers, J., Rockström, J., Stoknes, P. E.,Goluke, U., Collste, D., and Cornell, S. (2018). Achieving the 17 sustainable development goals within 9 planetary boundaries. Glob. Sust. 2:e24. doi: 10.31223/OSF.IO/XWEVB

Raven, R. P. J. M., and Gregersen, K. H. (2007). Biogas plants in Denmark: successes and setbacks. Renew. Sust. Energ. Rev. 11, 116-132. doi: $10.1016 /$ j.rser.2004.12.002

Reich, M., Aghajanzadeh, T., and De Kok, L. J. (2014). "Physiological basis of plant nutrient use efficiency - concepts, opportunities and challenges for its improvement," in Nutrient Use Efficiency in Plants, Vol. 10, eds M. Hawkesford, S. Kopriva, and L. De Kok (Cham: Springer).

Rittel, H. W. J., and Webber, M. M. (1973). Dilemmas in a general theory of planning. Policy Sci. 4, 155-169. doi: 10.1007/BF01405730

Ritzer, G. (2013). "An introduction to mcdonaldization," in The McDonaldization of Society, editor G. Ritzer (Los Angeles, CA: Sage), 1-26.

Rockström, J., Williams, J., Daily, G., Noble, A., Matthews, N., Gordon, L., et al. (2017). Sustainable intensification of agriculture for human prosperity and global sustainability. Ambio 46, 4-17. doi: 10.1007/s13280-016-0793-6

Rosset, P. (2008). Food sovereignty and the contemporary food crisis. Development 51, 460-463. doi: $10.1057 /$ dev.2008.48
Ryan, S. F., Adamson, N. L., Aktipis, A., Andersen, L. K., Austin, R., Barnes, L., et al. (2018). The role of citizen science in addressing grand challenges in food and agriculture research. Proc. Biol. Soc. 285:20181977. doi: 10.1098/rspb.2018.1977

Schäfer, T., and Kieslinger, B. (2016). Supporting emerging forms of citizen science: a plea for diversity, creativity and social innovation. J. Sci. Commun. 15:Y02. doi: $10.22323 / 2.15020402$

Schermer, M. (2015). "From food from nowhere" to "food from here:" changing producer-consumer relations in Austria. Agric. Human Values 32, 121-132. doi: 10.1007/s10460-014-9529-z

Schillo, R. S., and Robinson, R. M. (2017). Inclusive innovation in developed countries: the who, what, why, and how. Technol. Innov. Manage. Rev. 7, 34-46. doi: 10.22215/timreview/1089

Schneider, M., and McMichael, P. (2010). Deepening, and repairing, the metabolic rift. The Journal of Peasant Studies 37, 461-484. doi: 10.1080/03066150.2010.494371

Schulte, R. P. O., O'Sullivan, L., Vrebos, D., Bampa, F., Jones, A., and Staes, J. (2019). Demands on land: mapping competing societal expectations for the functionality of agricultural soils in Europe. Environ. Sci. Policy 100, 113-125. doi: 10.1016/J.ENVSCI.2019.06.011

Sherwood, J. (2020). The significance of biomass in a circular economy. Biores. Technol. 300:122755. doi: 10.1016/j.biortech.2020.122755

Shirk, J. L., Ballard, H. L., Wilderman, C. C., Phillips, T., Wiggins, A., Jordan, R., et al. (2012). Public participation in scientific research: a framework for deliberate design. Ecol. Soc. 17:29. doi: 10.5751/ES-04705170229

Spiegal, S., Kleinman, P. J. A., Endale, D. M., Bryant, R. B., Dell, C., Goslee, S., et al. (2020). Manuresheds : advancing nutrient recycling in US agriculture. Agric. Syst. 182:102813. doi: 10.1016/j.agsy.2020.102813

Spiller, K. (2012). It tastes better because consumer understandings of UK farmers' market food. Appetite 59, 100-107. doi: 10.1016/j.appet.201 2.04 .007

Steffen, W., Richardson, K., Rockström, J., Cornell, S. E., Fetzer, I., Bennett, E. M., et al. (2015). Planetary boundaries: Guiding human development on a changing planet. Science 347, 6223. doi: 10.1126/science. 1259855

Tilman, D., Cassman, K. G., Matson, P. A., Naylor, R., and Polasky, S. (2002). Agricultural sustainability and intensive production practices. Nature 418, 671-677. doi: 10.1038/nature01014

Tilman, D., and Clark, M. (2014). Global diets link environmental sustainability and human health. Nature 515, 518-522. doi: 10.1038/nature 13959

Tuomisto, H. L., and Helenius, J. (2008). Comparison of energy and greenhouse gas balances of biogas with other transport biofuel options based on domestic agricultural biomass in Finland. Agric. Food Sci. 17, 240-251. doi: $10.2137 / 145960608786118857$

UN (1948). The Universal Declaration of Human Rights. Resolution 217 A Adopted by the General Assembly on 10 December 1948. Paris: United Nations General Assembly. Available online at: https://www.un.org/en/ga/search/view_doc.asp? symbol=A/RES/217(III)

UN (2015). Transforming our world: the 2030 Agenda for Sustainable Development. Resolution A/RES/70/1 Adopted at the United Nations Sustainable Development Summit on 25 September 2015. United Nations High-level Political Forum on Sustainable Development. Available online at: https://www. un.org/en/development/desa/population/migration/generalassembly/docs/ globalcompact/A_RES_70_1_E.pdf

Uwizeye, A., Gerber, P. J., Schulte, R. P. O., and De Boer, I. J. M. (2016). A comprehensive framework to assess the sustainability of nutrient use in global livestock supply chains. J. Clean. Prod. 129, 647-658. doi: 10.1016/j.jclepro.2016.03.108

van der, Z. B., Levitt, T., and McSweeney, E. (2020). "'Chaotic and crazy': meat plants around the world struggle with virus outbreaks," in The Guardian. Available online at: https://www.theguardian.com/environment/2020/may/ 11/chaotic-and-crazy-meat-plants-around-the-world-struggle-with-virusoutbreaks (accessed May 11, 2020).

Wezel, A., Bellon, S., Dor,é, T., Francis, C., Vallod, D., and David, C. (2009). Agroecology as a science, a movement and a practice. A review. Agron. Sust. Dev. 29, 503-515. doi: 10.1051/agro/2009004

Wezel, A., Brives, H., Casagrande, M., Clement, C., Dufour, A., and Vandenbroucke, P. (2016). Agroecology territories: places for 
sustainable agricultural and food systems and biodiversity conservation. Agroecol. Sust. Food Syst. 40, 132-144. doi: 10.1080/21683565.2015.11 15799

Wheeler, T., and von Braun, J. (2013). Climate change impacts on global food security. Science 341, 508-513. doi: 10.1126/science.1 239402

Wilkins, J. L. (2005). Eating right here: Moving from consumer to food citizen. Agric. Human Values 22, 269-273. doi: 10.1007/s10460-005$6042-4$

Willett, W., Rockström, J., Loken, B., Springmann, M., Lang, T., Vermeulen, S., et al. (2019). Food in the anthropocene: the EAT-lancet commission on healthy diets from sustainable food systems. Lancet 393, 447-492. doi: 10.1016/S0140-6736(18)31788-4

Wittman, H. (2009). Reworking the metabolic rift: La Vía Campesina, agrarian citizenship, and food sovereignty. J. Peas. Stud. 36, 805-826. doi: $10.1080 / 03066150903353991$

Woods, M. (2012). Rural geography III: rural futures and the future of rural geography. Progr. Human Geogr. 36, 125-134. doi: 10.1177/0309132510393135
Zhang, W., Gowdy, J., Bassi, A. M., Santamaria, M., DeClerck, F., Adegboyega, A., et al. (2018). "Systems thinking: an approach for understanding 'eco-agri-food systems," in TEEB for Agriculture \& Food: Scientific and Economic Foundations (Genova, Switzerland: The Economics of Ecosystems and Biodiversity), 17-55. Available online at: http://teebweb.org/wp-content/uploads/2018/11/ Foundations_Report_Final_October.pdf

Conflict of Interest: The authors declare that the research was conducted in the absence of any commercial or financial relationships that could be construed as a potential conflict of interest.

Copyright $(0) 2020$ Helenius, Hagolani-Albov and Koppelmäki. This is an open-access article distributed under the terms of the Creative Commons Attribution License (CC BY). The use, distribution or reproduction in other forums is permitted, provided the original author(s) and the copyright owner(s) are credited and that the original publication in this journal is cited, in accordance with accepted academic practice. No use, distribution or reproduction is permitted which does not comply with these terms. 